\title{
Revisiting the Shariatism Thesis: Islam, Ethno- Natonalisme and the Remaking of Hybrid Identites in Post-Conflict Aceh, Indonesia
}

\author{
M. Alkaf ${ }^{1}$, Irwan Abdullah ${ }^{2}$, Zuly Qodir $^{3}$, Hasse Jubba ${ }^{4}$ \\ \{alkaf.muchtar@gmail.com ${ }^{1}$, irwan.fib@ugm.ac.id ${ }^{2}$, zulyqodir@umy.ac.id ${ }^{3}$, hasse@umy.ac.id ${ }^{4}$ \} \\ Islamic Politics-Political Science Universitas Muhammadiyah Yogyakarta ${ }^{1,3,4}$, Gadjah Mada \\ University $^{2}$,
}

\begin{abstract}
This study discusses the intersections of religion, ethnicity and nationalism in the post-conflict of Aceh, which focuses on the construction of Aceh hybrid identities. Based on empirical data of interviews, observation and documentation collected from 2017 to 2021, this study argues the victory of Shariatism in remaking of Acehnese contemporary identity discourse. This study also argued that the development of post-conflict local democracy contributes This study discusses the intersections of religion, ethnicity and nationalism in the post-conflict of Aceh, which focuses on the construction of Acehnese hybrid identities. Based on empirical data of interviews, observation and documentation collected from 2017 to 2012, this study argues the victory of Shariatism in remaking of Acehnese contemporary identity discourse. This study also argues that the development of post-conflict local democracy contributes significantly to the construction of hybrid identities in Aceh, which is more dominated by ethnonationalism than Shariatism and Islamism ideology. To defend this theory, the authors explore three pivotal aspects, including the consistent victory of a local political party in Aceh which carries the idea of Acehnese nationalism in three post-conflict elections; the reception and Acehnese custom and cultural dominance against Sharia canons; and integration of Ahlul Sunnah Wal Jamaah doctrine. This study concludes that the local democracy in the post-conflict of Aceh contributes significantly to the formation of the hybrid identities which are dominated by the idea of ethnonationalism than Islamism. The formation then eliminates the binary opposition and reconstructs a new identity in the post-conflict of Aceh.
\end{abstract}

Keywords: Shariatism; ethnonationalism; hybrid identities; post-conflict of Aceh

\section{Introduction}

The implication of growing local democracy emerges after the post-conflict in Aceh Province, Indonesia, due to the identity crosses of Islam and ethnonationalism. Most people still consider that both identities are in binary opposition and mutually competing. Despite the 
sixteen years of peace made, numerous regulations are issued by the local democracy, specifically related to the interpretation of Sharia ideas, which regulate Muslims' behaviors in Aceh (Feener, 2012) and the idea of ethnonationalism (Nurrahmi, 2018). Ichwan, Salim, and Srimulyani (2020) believe that the construction of new citizens' identity in Aceh is based on the ethnonationalism of religion. It arises through the strong influence of Sharia, which has become social, cultural, political, and legal facts.

So far, studies related to the identity in the Aceh post-conflict Aceh tend to examine two issues. The first issue focuses on the landslide victory of the Sharia narrative in Aceh. As indicated by Salim (2004) that Sharia is the identity that comes from lower aspiration. Srimulyani (2013) also shares the same idea that the identity of Islam and Acehnese was born from the history of modern Islamic schools in Aceh as a response to Western modernity. The idea of the Sharia implementation in Aceh then received the support of the ulama in Himpunan Ulama Dayah Aceh (the Association of Ulama Dayah Aceh) (Firdaus, Amiruddin, \& Drajat, 2017). Such support occurred due to the strategic position of the ulama within the Acehnese people (Alfian, 1975; Muntasir, 2018). In addition, those Islamic scholars were involved in critical phases of Aceh history, such as in the conflict, tsunami and peace processes (Barter, 2011; Widianti, 2006). Meanwhile, the second issue gives great attention to the formation of ethnonationalism because of the results of conflict factors (Aspinall, 2009; Bertrand, 2003; McCarthy, 2007; Schulze, 2004). Both issues above show that studies regarding the identity of Aceh tend to ignore their intersection and widely argue to the two opposing identities, whereas the growing local democracy in the post-conflict has led to the formation of hybrid identities amid the Acehnese people.

This study aims to complement the deficiency of previous studies, which have less attention to the problem diversity of identities. In particular, this study indicates that the hybrid identities in the post-conflict of Aceh are the central dimension proved by various parties, which involved in the political dynamics. In line with that, this paper also proposes arguments that the local democracy in the post-conflict of Aceh has contributed significantly to the formation of the hybrid identities, where ethnonationalism is quite dominant compared with Islamic and Sharia ideologies. To defend the theory, the authors discuss three themes, namely a consistent triumph of Partai Aceh (a local political party) carrying the ideas of nationalizing Aceh in three times of the post-conflict election; the receptions and domination of Acehnese customs and cultures to the Sharia canons; and integrating the doctrine of Ahl Sunnah wal Jamaah (Aswaja) to the Acehnese people.

That the arguments of the local democracy have given contributions to the establishment of the hybrid identities in Aceh have enlightened a new perspective of the social changes after the conflict. It is possible to happen since the electoral situations after the peace resolution run appropriately. In addition, the public in Aceh joins to support the birth of ideas discussed by various parties. The ideas - Sharia, ethnonationalism and religious orientation - have become a hot issue in Aceh, where the well-growing local democracy provides spaces, so the issue turns into a mutual discourse.

This qualitative study relies on primary and secondary data. The former was obtained from the direct observation of field studies and mapping of research aspects. Data needed to cover the three themes - the consistent winning election of Partai Aceh; the reception and domination of Acehnese customs and cultures against Sharia canons; doctrine integration of Aswaja. The data collection of the themes was carried out through observation, interview and related documentation. Moreover, this study involved two parties as informants in data collection, namely the politicians from Partai Aceh and ulama from the dayah association of Aceh. Both parties were involved to examine how the diversity of identity has significance in 
the discourse interpretation and intersection growing in the post-conflict of Aceh. The research process lasted two months, starting from the desk review, field observation and interview. Prior to conducting the field observation, the authors collected various secondary sources, online news, for instance, to map the hybrid identities that occurred textually. The observation was conducted in several meeting rooms, where the hybrid identities of the informants could be observed directly. Then, the interview was categorized the informants into three groups for mapping purposes. It was done by direct communication with them through phone calls after getting their approval. The data analysis was carried out in two phases (Sugiono, 2016). First, it was progressed before the research process was initiated. Second, the analysis was deployed during the data collection and after the data accumulation for a certain period.

\section{Findings \& Discussion}

\subsection{The Consistent Triumphs of Partai Aceh}

Partai Aceh is a continuation of the resistance organization in the post-conflict of Aceh, Gerakan Aceh Merdeka (Free Aceh Movement). This movement is different from Darul Islam, which carries the idea of Islam and ethnonationalism (Aspinall, 2009). This fight appeared when the Central Government of Indonesia was in a solid position, particularly after the New Order conducted the first election in 1971, which was won by its political machine, Partai Golongan Karya. Aceh did not conducive at that time as the result of the political policy of the Central Government, which exploited the natural sources of Aceh without having fair developments. In addition, culturally, there was a disappointment of the Acehnese people because the regime rejected the draft proposed by the local parliament of Aceh, which offered the layout of the Sharia implementation in 1969 (Nashir, 2013). As a reason for the resistance, Hasan Tiro proposed two theories - the return of Aceh to Indonesia is not valid based on international law and there is no historical relationship between Aceh and Indonesia (F. Ali, Monoarfa, \& Effendy, 2008). Then, the long history of fighting between the Free Aceh Movement and Indonesia eventually ended up in the table of negotiation called the Memorandum of Understanding (MoU) in Helsinki. This peace agreement resulted in many compensations, both economics and politics, which were given to Aceh through Act No. 11 of 2006 related to the Government of Aceh. The regulation allows Aceh has its local political parties that can participate in regional legislative elections and regional head elections (Pilkada).

After getting the peace agreement, Partai Aceh continued the ethnonationalism from the previous idea, Free Aceh Movement. Even before the arrivals of local parties, the excombatants of the Free Aceh Movement nominated themselves individually as the candidate of regional heads in the 2006 election. They got an absolute win. Even the representative of Partai Aceh like Irwandi Yusuf and Muhammad Nazar won the governor election of Aceh from 2007 to 2012 (Aceh, 2016). Some combatants of the resistance also won other regional elections (Nurhasim, 2016a). This consistent victory continued in the next elections. This fact shows that the political transformation has succeeded happened in the body of resistance organizations (M. R. H. Ali \& Patria, 2009; Nurhasim, 2016b; Stange \& Patock, 2010). The continuing political triumph until the 2019 election made Partai Aceh advance the old political agenda, such as integrating the canons of the flag, symbol and hymn of Aceh. Nonetheless, although the number of votes continues to decline in previous elections (Setyadi, 2018), its significant political power is, even more, be strategic to determine the populist direction of 
policymaking, such as participating to reject the agenda of revising canon about the Sharia financing institutions (Aceh.tribunnews.com, 2021). However, the steps taken by Partai Aceh are only a political debate. It is not substantive since the formalism of Islam in Aceh is disintegrated. Besides, the legal products issued by the party are contra-productive to the social order of Acehnese people since the current needs are cultural and economic politics (interview with Juanda Jamal, September 4, 2021).

\subsection{The Subjection of Sharia Canons by the Acehnese Customs and Cultures}

In the seminar of a book entitled 'Sharia and Human Rights: Learning from Experience of Acehnese People' at Universitas Muhammadiyah Malang (umm.ac.id, 2018), Siti Ruhaini Dzuhayatin recounted her experiences when having a dialogue with Al Yasa Abu Bakar. She wondered that Aceh would apply hukum rajam (the law of stoning). Al Yasa replied that such a thing was not ever happened in the past of Aceh. Al Yasa is the first Head of the Provincial Sharia Office of Aceh. During his leadership, Sharia enforcement was initiated in Aceh at the beginning of the 2000s. To provide a philosophical base of which, he wrote a book depicting the ideas and practices of Sharia implementation (Abubakar, 2005). From his book, the authors found that the Sharia implementation in Aceh did not refer to Middle East countries or Aceh in the past. Al Yasa did not integrate hudud (Islamic penal law or Quranic punishments), instead, he preferred to bring the concept of tazir. It is a law established by a government that interprets the law.

The concrete form of avoiding the Islamic influence of the Middle East countries also provides the most moderate interpretation regarding the rules of aurat (body parts required to be covered in Islam) for women. When Sharia-applying countries such as Pakistan (Critelli, 2010), Saudi Arabia (Quamar, 2016), Iran (Shirazi, 2019), and Afghanistan (Berry, 2003) have a rule of asking women to cover their aurat, the Government of Aceh constructs a similar canon requiring women to cover their body except for the hand palms of their daily clothing. This regulation is a way to perform the customs and cultures of Aceh in subjecting the Sharia.

The same circumstance also happened when the polemic of revising Jinayah canon, which was revised substantially. The subjection of customs and cultures of Aceh was seen when Governor Irwandi Yusuf refused to insert the phrase hukum rajam in the revision (liputan6.com, 2009) 2009). He reasoned that such law was contrary to national and international law (antaranews.com, 2009). Even though he served for two periods as the Governor of Aceh, he kept issued the policy, which was not populist regarding flogging penalty in a closed room for Sharia violators. He made the excuse that the convicts' investment and honor could be condemned for the rest of their life due to videos recorded by the attending communities during the punishment. He added that the media might spread on digital platforms when the penalty was executed in an open space (bbc.com, 2018).

\subsection{Aswaja among Acehnese People}

Based on the information from digital media platforms (Majelis Ulama TV, 2018), Bulqaini Tanjungan, familiarly called by Tu Bulqaini, stood up in front of his supporters who cheered for the victory. Their expressions were like they had just won a war. Bulqaini gave his victory speech over the success of several dayah groups of Aceh seized Masjid Agung Al Makmur Lamprit in Banda Aceh, from the control of Salafi groups. He emphasized that what had they done was to maintain the teaching of Aswaja, which became the most legitimate Islamic teaching in Aceh. The legitimation has occurred long since the days of the Kingdom of 
Iskandar Muda.

A similar argument was also by Muhammad Amin or known as Tu Min, an Acehnese ulama of the Islamic tradition frontline (Majelis Ulama TV, 2020). He expressed his opinion that Aswaja should win in a dispute of Islamic discourse in Aceh on the event of Muzakarah Ulama Aceh (a big discussion forum of Acehnese ulama) in 2015. Tu Min became one of the teams in formulating the result of the forum. In front of other members, particularly the Islamic modernists like Farid Wajdi, Sheikh Syamaun Risyad and Syahrizal Abbas, Tu Min conveyed that Aswaja in Aceh referred to Sheikh Abdurrauf as-Singkili. Since the $17^{\text {th }}$ century, he becomes as the reference by traditions as a base of such Islamic discourse conducted for generations.

The efforts to integrating Aswaja among Acehnese people are constructed with the genealogical discourses, so the Salafi groups are concerned discordant with the Islamic cultures of the Acehnese people. The conflicts with them became worse due to the use of governmental institutions to forbid the groups (Setyadi, 2019). Moreover, that the protest against the Salafis triggers the parade of Aswaja asserts that there is a tension of Islamic teachings in Aceh, which is determined by the narrative of cultural identity that appeared among societies. It argues the most Islamic teaching represents the Acehnese cultures (Miswar, 2017, 2019).

The narrative of the most representing Aswaja also encompasses the debate regarding Zakat al-Fitr, which is ruled in the Shafi'i school of figh and the more modern canons. The dayah ulama, who controlled the Assembly Consultative Ulama of Aceh, issued a fatwa No. 13 of 2014 regarding Zakat al-Fitr and Its Provisions, while canons are ascertained with the views of Shafiah fiqh considering staple foods as the Zakat al-Fitr. Meanwhile, as a Sharia formalism ideologue in Aceh, Al Yasa attempted to share his different views about Zakat alFitr (Abubakar, 2020). The success of giving the true meaning of Aswaja by those traditional Islamic groups in Aceh is due to the vertical mobility, which is done by the groups for decades. In addition, the networking spread of dayah in each region of Aceh also contributes to the accomplishment (interview with MI, September 4, 2021). At the same time, the position of ulama is getting stronger by the formalism of Sharia in Aceh. The dayah ulama considers that the Sharia implementation is a way of the Central Government to protect Islam (interview with Wildan, September 4, 2021).

This paper showcases that the hybrid identities - the intersection between Islamism and ethnonationalism - have been occurred. Three typologies may elaborate the manifestation of the identities. First, the consistent victory of Partai Aceh as the continuation of the Free Aceh Movement brings the idea of ethnonationalism, especially when the movement resisted the Central Government. The party also always strives for such an idea to be realized in the national scheme. The next typology is the subjection of Sharia by the Acehnese customs and cultures. From the beginning, the formalism of Sharia in Aceh avoided the dominance of Islamism from the Middle East countries. Therefore, the fiqh included in the Sharia canons is included from the common religious practices in Aceh. Third, integrating Aswaja within Acehnese people shows that the formalism of Sharia cannot be separated from the local traditions growing for a long time. The attempt to dominate the tradition toward Shariatism, hence, indicates that there is no identity, which reaches a landslide victory.

The hybrid identities growing in the post-conflict of Aceh were due to the contribution of local democracy that also grew at the same time. The local democracy, nonetheless, undergoes in order. The combatants of the Free Aceh Movement succeeded in transforming from armed groups into civilians. Besides, groups of ulama and dayah students also retrieve a strategic position within the Acehnese people after the post-conflict. It is due to their political 
recognition through the acceptance of religious interpretations they have in wider society. At the same time, the Islamic modernists, who become the backbone of the formalism Sharia implementation in Aceh, are not eliminated. Even they receive the benefits of mobility vertical groups of combatants and Islamic traditions.

Therefore, aforementioned studies tend to view at two issues - the study of identity that confirms the landslide victory of the Sharia narrative in Aceh (Alfian, 1975; Barter, 2011; Feener, 2012; Firdaus et al., 2017; Muntasir, 2018; Salim, 2004; Srimulyani, 2013; Widianti, 2006) and the study of Acehnese identity that focuses on the formation of ethnonationalism as a result of conflict factors (Aspinall, 2009; Bertrand, 2003; McCarthy, 2007; Schulze, 2004). Accordingly, this study is different from the two tendencies above since it highlights the intersection of identities growing, hence, it forms the hybrid identities and negates the binary opposition.

\section{Conclusion}

The analysis of the growth of the hybrid identities in the post-conflict of Aceh has allowed the discovery of two vital things. First, a good democracy always allows every thought to meet in a public space fairly. Second, the local democracy in Aceh, which grew in the post-conflict, has opened the deliberative space. It means that every idea based on variants of identity in Aceh reciprocate each other, which eventually forms hybrid identities.

Nevertheless, this study is limited to the analysis of three theories and is based on the informants' views. The analysis does not make the results as a reference to describe differences of the meanings on the wider spectrums. Also, the informants' views as the basic inference on the hybrid identities do not provide a clear picture about the formation of new identities in the post-conflict of Aceh. Hence, with those limitations, further research needs to pay attention to the dimensions of comparison territorially. Too, the informants are more varied and sourced at more diverse data.

\section{Acknowledgements}

I would like to thank Muhammad Ansor for the input to accomplish this research. I also would like to thank all the interviewees, including local party politicians, academics, and ulama in Aceh.

\section{Reference}

[1] Abubakar, A. Y. (2005). Syariat Islam di Provinsi Nanggroe Aceh Darussalam: Paradigma, Kebijakan, dan Kegiatan. Banda Aceh: Dinas Syariat Islam Provinsi Nanggroe Aceh Darussalam.

[2] Abubakar, A. Y. (2020). Zakat Fitrah: Dalam Qanun Aceh Zakat Fitrah: Dalam Qanun Aceh. Retrieved September 4, 2021, from aceh.tribunnews.com website: https://aceh.tribunnews.com/2020/05/13/zakat-fitrah-dalam-qanun-aceh.

[3] Aceh.tribunnews.com. (2021). PA Tolak Revisi Qanun LKS, Sebut Ada Upaya Mengkerdilkan Keistimewaan Aceh. Retrieved September 4, 2021, from aceh.tribunnews.com website: https:/aceh.tribunnews.com/2021/07/25/pa-tolak-revisi- 
qanun-lks-sebut-ada-upaya-mengkerdilkan-keistimewaan-aceh

[4] Aceh, M. C. K. (2016). https://kip.acehprov.go.id/data-fakta-pilkada-aceh-2006-dan2012/. Retrieved September 4, 2021, from kip.acehprov.go.id website: https://kip.acehprov.go.id/data-fakta-pilkada-aceh-2006-dan-2012/

[5] Alfian, A. (1975). The Ulama in Acenese Society: A Preliminary Observation Author. Southeast Asian Journal of Social Science, 3(1), 27-41.

[6] Ali, F., Monoarfa, S., \& Effendy, B. (2008). Kalla dan Perdamaian Aceh. Jakarta: Lembaga Studi dan Pengembangan Etika Usaha Indonesia.

[7] Ali, M. R. H., \& Patria, N. (2009). Dari Kontak Senjata ke Kotak Suara: Peralihan Gerakan Aceh Merdeka ke Politik Elektoral. Prisma.

[8] antaranews.com. (2009). Pakar Hukum: Qanun Jinayat Agar Dibahas Ulang. Retrieved September 4, 2021, from antaranews.com website: https:/www.antaranews.com/berita/159316/pakar-hukum-qanun-jinayat-agar-dibahasulang

[9] Aspinall, E. (2009). Islam and Nation: Separatis Rebellion in Aceh, Indonesia. Stanford, California: Stanford University Press.

[10] Barter, S. J. (2011). Ulama, the state, \& war: Community Islamic leaders in the Aceh conflict. Contemporary Islam, 5(1), 19-36. https://doi.org/10.1007/s11562-010-0141-8

[11] bbc.com. (2018). Alasan investasi, hukuman cambuk di Aceh dipindah ke dalam LP. Retrieved September 4, 2018, from bbc.com website: https://www.bbc.com/indonesia/indonesia-43739493

[12] Berry, K. (2003). The Symbolic Use of Afgan Women in The War on Teror. Humboldt Journal of Social Relations, 27(2), 137-160. https://doi.org/https://www.jstor.org/stable/23524156

[13] Bertrand, J. (2003). Nationalism and ethnic conflict in Indonesia. In Nationalism and Ethnic Conflict in Indonesia. https://doi.org/10.1017/CBO9780511559341

[14] Critelli, F. M. (2010). Beyond the Veil in Pakistan. Affilia, 25(3), 236-249. https://doi.org/10.1177/0886109910375204

[15] Feener, R. M. (2012). Social engineering through Sharī'a: Islamic law and statedirected da'wa in contemporary aceh. Islamic Law and Society, 19(3), 275-311. https://doi.org/10.1163/156851911X612581

[16] Firdaus, F., Amiruddin, H., \& Drajat, A. (2017). The Role of HUDA in the Implementation of Islamic Syari' ' ah in Aceh. IOSR Journal Of Humanities And Social Science (IOSR-JHSS), 22(5), 15-22. https://doi.org/10.9790/0837-2205111522

[17] Ichwan, M. N., Salim, A., \& Srimulyani, E. (2020). Islam and Dormant Citizenship: Soft Religious Ethno-Nationalism and Minorities in Aceh, Indonesia. Islam and Christian-Muslim Relations, $\quad 0(0), \quad 1-26$. https://doi.org/10.1080/09596410.2020.1780407

[18] liputan6.com. (2009). Gubernur Aceh Tetap Tolak Qanun Rajam. Retrieved September 4, 2021, from liputan6.com website: https://www.liputan6.com/news/read/249131/gubernur-aceh-tetap-tolak-qanun-rajam

[19] Majelis Ulama TV. (2018). Tu Bulqaini Sampaikan Tausyiah Pasca Kericuhan di Masjid Oman. Retrieved from https://www.youtube.com/watch?v=Wcki0eMbHcM

[20] Majelis Ulama TV. (2020). Tu Min, Abu Kuta Krueng dan Abu Paloh Gadeng Membahas Persoalan Umat. Retrieved from https://www.youtube.com/watch?v=IEfaAB8aBGI

[21] McCarthy, J. F. (2007). The demonstration effect: Natural resources, ethnonationalism and the Aceh conflict. Singapore Journal of Tropical Geography. 
https://doi.org/10.1111/j.1467-9493.2007.00304.x

[22] Miswar, K. (2017). Syariat dan Apa Ta'a: Fenoma Sosial Keagamaan Pasca Konflik Aceh. Banda Aceh: Padebooks.

[23] Miswar, K. (2019). Wahabi dalam Perspektif HUDA (Himpunan Ulama Dayah Aceh) dan Implikasiny terhadap Kehidupan Sosial Keagamaan di Aceh. Universitas Islam Negeri Ar Raniry Banda Aceh.

[24] Muntasir. (2018). The Social Role of Ulama Dayah to Aceh Society, Indonesia. 23(1), 18-24. https://doi.org/10.9790/0837-2301051824

[25] Nashir, H. (2013). Islam Syariat: Reproduksi Salafiyah Ideologis di Indonesia. Bandung: Mizan.

[26] Nurhasim, M. (2016a). Dominasi Partai Aceh Pasca MoU Helsinki. Jurnal Penelitian Politik, 9(2), 1-15.

[27] Nurhasim, M. (2016b). Transformasi Politik Gerakan Aceh Merdeka (GAM). Jurnal Penelitian Politik, 6(1), 85-98.

[28] Nurrahmi, F. (2018). The Narrative of Identity in the Coverage of Aceh's Flag. Jurnal Studi Komunikasi, 2(2), 213-231. https://doi.org/10.25139/jsk.v2i2.780

[29] Quamar, M. M. (2016). Sociology of the Veil in Saudi Arabia: Dress Code, Individual Choices, and Questions on Women's Empowerment. DOMES:Digest of Middle East Studies, 1-23. https://doi.org/10.1111/dome.12085

[30] Salim, A. (2004). "Shari'a from below" in Aceh (1930s-1960s): Islamic identity and the right to self-determination with comparative reference to the Moro Islamic Liberation Front (MILF). Indonesia and the Malay World, 32(92), 80-99. https://doi.org/10.1080/1363981042000263471

[31] Schulze, K. (2004). The Free Aceh Movement (GAM) : anatomy of a separatist organization.

[32] Setyadi, A. (2018). Perolehan Kursi Turun, Caleg Partai Aceh Dinilai Kurang Pengaruh. Retrieved September 4, 2021, from detik.com website: https://news.detik.com/berita/d-4551885/perolehan-kursi-turun-caleg-partai-acehdinilai-kurang-pengaruh

[33] Setyadi, A. (2019). Pemprov Aceh Larang Pengajian Selain Ahlusunah WaljamaahMazhab Syafi'iyah. Retrieved September 4, 2021, from detik.com website: https://news.detik.com/berita/d-4840094/pemprov-aceh-larang-pengajian-selainahlusunah-waljamaah-mazhab-syafiiyah

[34] Shirazi, F. (2019). The Veiling Issue in 20th Century Iran in Fashion and Society, Religion, and Government. Religions, 10(461), 1-31. https://doi.org/10.3390/rel10080461

[35] Srimulyani, E. (2013). Islamic Schooling in Aceh: Change, Reform, and Local Context Abstract: 20(3), 467-487. https://doi.org//10.15408/sdi.v20i3.513

[36] Stange, G., \& Patock, R. (2010). From Rebels to Rulers and Legislators: The Political Transformation of the Free Aceh Movement (GAM) in Indonesia. Journal of Current Southeast Asian Affairs, 29(1), 95-120. https://doi.org/10.1177/186810341002900105

[37] Sugiono. (2016). Metode Penelitian Kuantitatif, Kualitatif, dan R\&D. Bandung: PT Alfabet.

[38] umm.ac.id. (2018). PUSAM UMM Ajak Tilik Lebih dalam "Kehidupan Syariah" di Aceh. Retrieved September 4, 2021, from umm.ac.id website: https://www.umm.ac.id/id/berita/pusam-umm-ajak-tilik-lebih-dalam-kehidupansyariah-di-aceh.html

[39] Widianti, E. (2006). The Ulama in Aceh in Time of Conflict, Tsunami and Peace 
Process: An Etnographic Approach. Ohio University.

[40] Abubakar, Al Yasa'. 2005. Syariat Islam Di Provinsi Nanggroe Aceh Darussalam: Paradigma, Kebijakan, Dan Kegiatan. Banda Aceh: Dinas Syariat Islam Provinsi Nanggroe Aceh Darussalam.

[41] Ali, Fachry, Suharso Monoarfa, and Bahtiar Effendy. 2008. Kalla Dan Perdamaian Aceh. Jakarta: Lembaga Studi dan Pengembangan Etika Usaha Indonesia.

[42] Aspinall, Edward. 2009. Islam and Nation: Separatis Rebellion in Aceh, Indonesia. Stanford, California: Stanford University Press.

[43] Bertrand, Jacques. 2003. Nationalism and Ethnic Conflict in Indonesia. Cambridge: Cambridge University Press.

[44] Miswar, Khairil. 2017. Syariat Dan Apa Ta'a: Fenoma Sosial Keagamaan Pasca Konflik Aceh. Banda Aceh: Padebooks.

[45] Miswar, Khairil. 2019. "Wahabi Dalam Perspektif HUDA (Himpunan Ulama Dayah Aceh) Dan Implikasinya Terhadap Kehidupan Sosial Keagamaan Di Aceh." Universitas Islam Negeri Ar Raniry Banda Aceh.

[46] Sugiono. 2016. Metode Penelitian Kuantitatif, Kualitatif, Dan R\&D. Bandung: PT Alfabet.

[47] Widianti, Ezki. 2006. "The Ulama in Aceh in Time of Conflict, Tsunami and Peace Process: An Etnographic Approach.” Ohio University. 